\title{
TRACE ELEMENT CARRIERS IN COMBINED SEWER DURING DRY AND WET WEATHER: AN ELECTRON MICROSCOPE INVESTIGATION
}

\author{
A.G. El Samrani*, B. S. Lartiges*(a) ${ }^{*}$ J. Ghanbaja*, J. Yvon* ${ }^{*}$ A. Kohler \\ *Laboratoire Environnement et Minéralurgie (LEM-ENSG) Pôle de l'Eau \\ 15, Avenue du Charmois -BP 40 - 54501 Vandœuvre, FRANCE \\ † Université Henri Poincaré - Service Commun de Microscopie Electronique \\ BP 239. 54500 Vandœuvre Cedex, FRANCE.
}

E-mail: Bruno.lartiges@get.omp.eu

(a) To whom correspondence should be addressed 


\begin{abstract}
The nature of trace element carriers contained in sewage and combined sewer overflow (CSO) was investigated by TEM-EDX-Electron diffraction and SEM-EDX. During dry weather, chalcophile elements were found to accumulate in sewer sediments as earlydiagenetic sulfide phases. The sulfurization of some metal alloys was also evidenced. Other heavy metal carriers detected in sewage include metal alloys, some iron oxihydroxide phases and neoformed phosphate minerals such as anapaite. During rain events, the detailed characterization of individual mineral species allowed to differentiate the contributions from various specific sources. Metal plating particles, barite from automobile brake, or rare earth oxides from catalytic exhaust pipes, likely originated from road runoff, whereas $\mathrm{PbSn}$ alloys and lead carbonates were attributed to zinc-works from roofs and paint from building siding. Soil contribution was traced by the presence of clay minerals, iron oxihydroxides, zircons and rare earth phosphates. However, the most abundant heavy metal carriers in CSO samples were the sulfide particles eroded from sewer sediments. The evolution of relative abundances of trace element carriers during a single storm event, suggests that the pollution due to the "first flush" effect mainly results from the sewer stock of sulfides and previously deposited metal alloys, rather than from urban surface runoff.
\end{abstract}

\title{
Keywords
}

Heavy metal, Speciation, Runoff, Storm water, Combined sewer overflows, SEM, TEM, EDX. 


\section{INTRODUCTION}

The impact of combined sewer overflows (CSO) upon quality of receiving aquatic systems is a major concern in environmental protection. In most cases, the pollution issued from CSO exceeds annual discharges from factories and sewage plants (Bedient et al., 1978; Ellis and Hvitved-Jacobsen, 1996). Contaminants in CSO are derived from a number of sources. Thus, materials from wet and dry atmospheric deposition, traffic-related activities (tire wear, vehicle brake emissions, fluid leakages), or released from roofs and building siding, may be flushed by rainfall and collected in the municipal sewer system (Mason et al., 1999; Davis et al., 2001). In addition, sewage and sewer-deposited material can also represent a significant contribution to CSO pollutant load (Gromaire et al., 2001).

Early work has focused on estimating the relative contributions of specific sources to CSO pollutant load in terms of total amount of heavy metals, hydrocarbons, nutrients... (Chebbo et al., 1995; Lee and Bang, 2000). However, this approach only provides a rough assessment of contaminant mobility and bioavailability in receiving waters, since pollutant behavior is mainly governed by its speciation (Morrison and Revitt, 1987; Florence et al., 1992; Perin et al., 1997). Indeed, heavy metals may be present under numerous physicochemical forms such as soluble, adsorbed on mineral surfaces, complexed with organic matter, precipitated or entrapped in mineral phases. Exchangeable forms are usually considered as immediately bioavailable species (Morrison and Revitt, 1987). The partitioning of metal contaminants between specific forms is classically determined using sequential extraction methods (Tessier et al., 1979; Lake et al., 1984; Serne, 1975). Thus, sorbed metal ions, metals associated with carbonates, iron and manganese oxihydroxides, sulfides, can be distinguished by adding appropriate reagents to the sample. Such procedures have been applied to separate CSO contributors such as street deposits (Morrison and Revitt, 1987), roof deposits (Förster, 1996), gully pot solids (Morrison et al., 1989; Butler et al., 1995) and combined sewer suspended solids of dry and wet weather (Gromaire et al., 2001).

However, it is now recognized that metal fractions obtained by selective chemical extraction procedures are only operationally defined, as incomplete dissolution of the target phase, dissolution of nontarget species, incomplete removal of dissolved species due to readsorption or precipitation, may occur (Ostergren et al., 1999; La Force and Fendorf, 2000). Furthermore, such speciation does not identify with certainty the various phases that may contain heavy metals. An alternative approach is to use microscopy techniques such as Transmission (TEM) and Scanning (SEM) electron microscopies combined with energy- 
dispersive X-ray spectrometry (EDX). TEM-EDX-Electron diffraction and SEM-EDX observations in Backscattered Electron Imaging mode allow direct determination of heavy metal occurrences and provide combined data on both mineralogy and texture of heavy metal carriers (de Boer and Crosby, 1995; Zaggia and Zonta, 1997; Buatier et al. 2001). Such information is essential for the description of trace element cycles in urban environment (Zaggia and Zonta, 1997). Knowledge of heavy metal-bearing species can also be useful to improve the management of sludges retained in detention basins or generated during physicochemical treatment of CSO. The aim of the present study was then to evaluate the use of TEM-EDX and SEM-EDX for determining the nature of heavy metal carriers contained in sewage and CSO.

\section{EXPERIMENTAL SECTION}

\section{Study site}

Samples (sewage and combined sewer overflow) were taken from the sewer pipe "Libération", up-stream Boudonville detention basin (figure 1). Boudonville watershed lies in the North West part of the city of Nancy (France) on the left bank of Meurthe River. The catchment area receives runoff from 246 ha of urban surfaces, both residential and commercial areas ( 20000 inhabitants), and is essentially drained with a combined sewer system (Marchand et al., 1993).

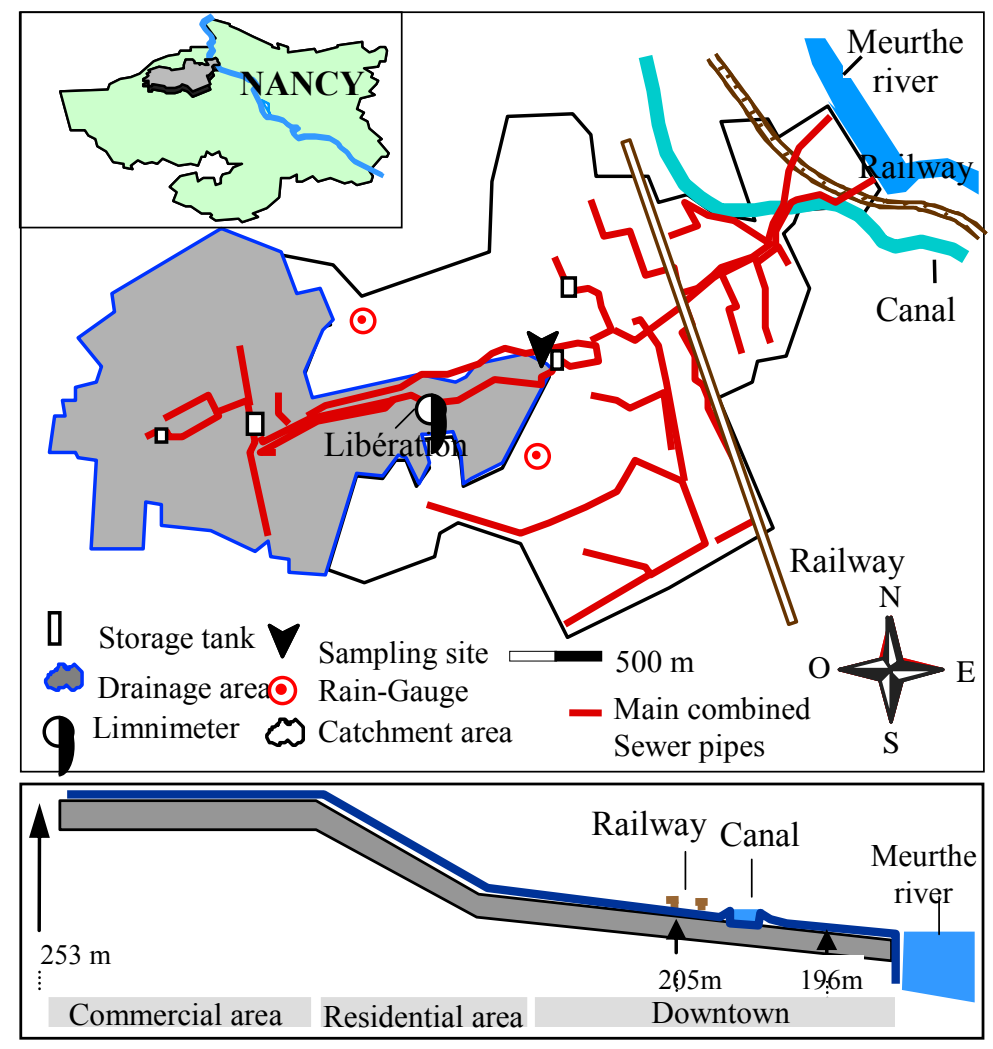

Figure 1. Study site location and map of Boudonville catchment area. 
The average slope of the watershed is $0.034 \mathrm{~m} / \mathrm{m}$ with about $40 \%$ of impervious surface. To prevent flooding at the lower part of the watershed during storm events, three detention tanks have been built. In consequence, Boudonville watershed has been equiped with 8 rain-gauges and 20 limnimeters, and has been used as an experimental catchment area for hydraulic and pollution transport studies for the past two decades (Marchand et al., 1993; Laurensot, 1998). In this study, data of "Libération" limnimeter and of 2 rain-gauge stations close to the sampling site, were graciously provided by Service Hydraulique of Nancy Urban Community.

\section{Sample collection and preparation}

Dry and wet weather flows (weak intensity rain events of long duration and storm events), were collected between June 2001 and April 2002. Samples, taken from the sewer using either a $1 \mathrm{~L}$ chemo-sampler (Fisher Scientific) or a peristaltic pump (Delasco "Z" - flow rate $\sim 5 \mathrm{~L} / \mathrm{min}$ ) (fig. 2a), were collected in $10 \mathrm{~L}$ polyethylene jerrycans, transported to the laboratory and processed in the first $\mathrm{h}$ after sampling.

The preparation procedure is schematized in figure $2 \mathrm{~b}$. After gentle over-end agitation of jerrycans, $1 \mathrm{~L}$ samples of raw water were taken and allowed to settle in Imhoff cones for two hours. This sedimentation time was selected to mimic large particle removal in conventional depollution tanks (Michelbach and Weib, 1996). It allows to separate a "settleable fraction" from a "suspended fraction". The "setteleable fraction" was centrifuged at $12000 \mathrm{rpm}(\sim 15000 \mathrm{~g})$ for 20 minutes (Beckman -L8-55M), and the sediment thus obtained was recovered and freeze dried (Virtic-Sentry). The "suspended fraction" was filtered without stirring through a $0.45 \mu \mathrm{m}$ pore size Nuclepore membrane (polycarbonate - diameter $60 \mathrm{~mm}$ ), and the filter was air dried at room temperature. 

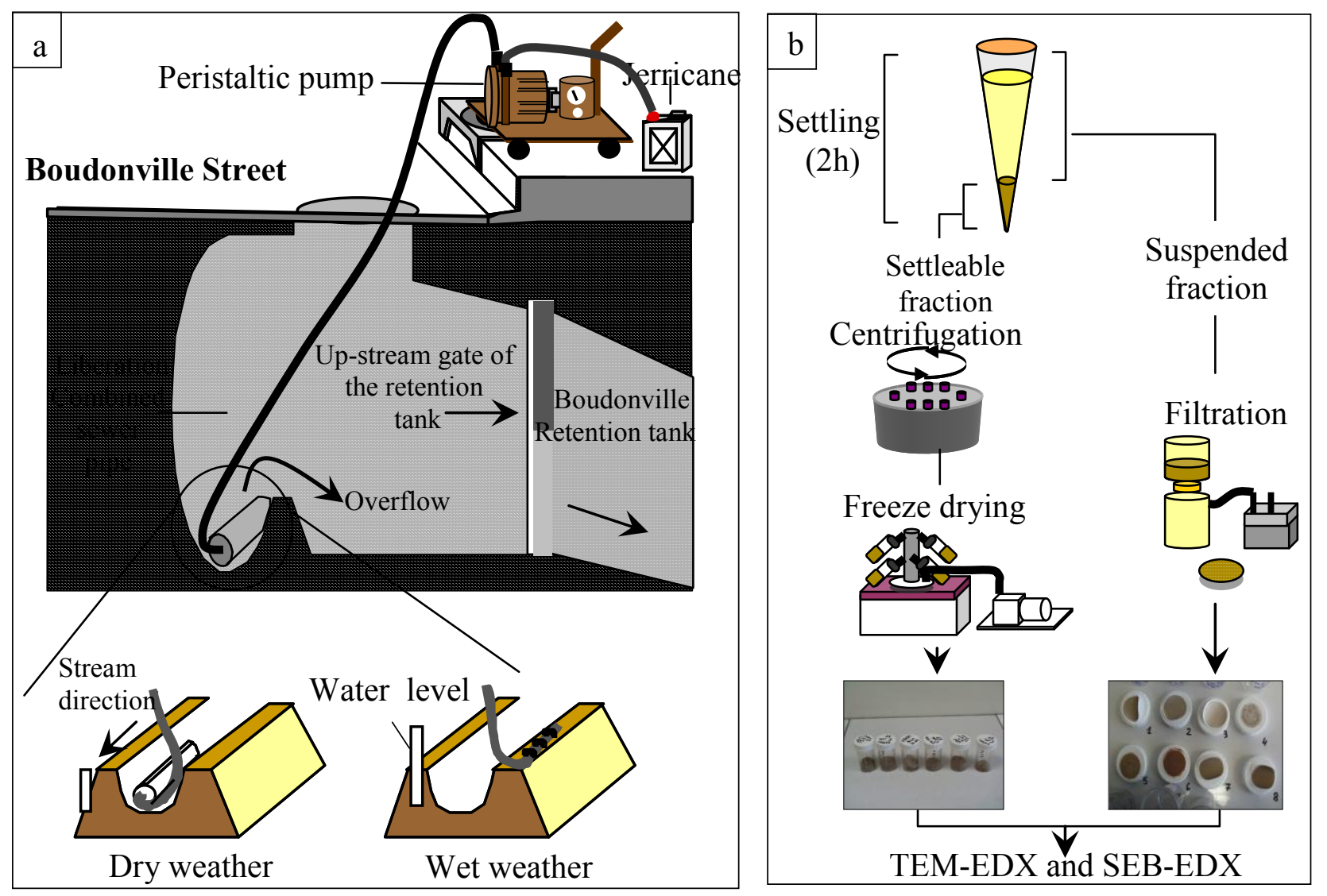

Figure 2. Schematics of (a) sampling procedure and (b) sample preparation.

\section{Trace element speciation by electron microscopy}

Electron microscopy observations were performed with a Philips CM20 TEM (200 $\mathrm{keV}$ ) coupled with an EDAX energy dispersive X-ray spectrometer (EDX), and with a S-2500 Hitachi SEM equipped with a Kevex 4850-S EDX. Trace element carriers were identified from elemental analysis of individual particles. Stoichiometric ratios were first calculated from atomic percentages given by EDX spectra, and then compared with known mineralogical compositions. Electron diffraction patterns provided by TEM were also used to specify the crystal structure of particles.

About 1250 mineral particles from samples of sewage, weak rain events, and storm events (table 1), were examined over the period of study (800 SEM-EDX spectra and 450 TEM-EDX spectra). For TEM imaging and microanalysis, the sample was re-suspended in ethanol under ultrasonication, and a drop of suspension was evaporated on a carbon-coated copper grid (EuroMEDEX, Mesh200-Car\#CF200CU). A spot size of about 70nm was used to 
record EDX spectra with a counting time of 40seconds. EDX calibration standards were run to obtain quantitative analyses of major and trace elements with a detection limit of about 100 ppm.

Table 1. Sampling dates and corresponding physicochemical characteristics of sewage and CSO during storms and weak rain events.

\begin{tabular}{|c|c|c|c|c|c|}
\hline & Date (M/D/Y) & $\begin{array}{c}\text { Suspended } \\
\text { solids (mg/L) }\end{array}$ & $\begin{array}{l}\text { Volatile solids } \\
\text { at } 550^{\circ} \mathrm{C}(\mathrm{mg} / \mathrm{L})\end{array}$ & pH & $\begin{array}{c}\text { Alkalinity } \\
\text { (meq/L) }\end{array}$ \\
\hline \multirow{4}{*}{$\begin{array}{c}\text { Sewage } \\
\text { (Dry weather) }\end{array}$} & 06-03-2001 & 785 & 523 & 7.63 & 1.51 \\
\hline & $10-30-2001$ & 980 & 590 & 7.58 & 1.70 \\
\hline & $02-28-2002$ & 835 & 562 & 7.35 & 1.61 \\
\hline & 04-18-2002 & 910 & 540 & 7.84 & 1.68 \\
\hline \multirow{4}{*}{$\begin{array}{c}\text { CSO } \\
\text { (weak rain } \\
\text { event) }\end{array}$} & 03-08-2001 & 165 & 98 & 6.10 & 0.12 \\
\hline & 09-19-2001 & 147 & 89 & 6.15 & 0.14 \\
\hline & $10-23-2001$ & 255 & 155 & 6.40 & 0.18 \\
\hline & $02-25-2002$ & 185 & 103 & 6.10 & 0.16 \\
\hline \multirow{10}{*}{$\begin{array}{c}\text { CSO } \\
\text { (storm event) }\end{array}$} & 05-14-2001 & 595 & 434 & 6.92 & 0.34 \\
\hline & 07-06-2001 & & & & \\
\hline & Local time $19 \mathrm{~h} 30 \mathrm{~min}$ & 750 & 410 & 7.32 & 1.44 \\
\hline & $19 \mathrm{~h} 37 \mathrm{~min}$ & 820 & 600 & 7.39 & 1.18 \\
\hline & $19 \mathrm{~h} 42 \mathrm{~min}$ & 840 & 470 & 7.44 & 0.54 \\
\hline & $19 \mathrm{~h} 45 \mathrm{~min}$ & 910 & 560 & 6.75 & 0.46 \\
\hline & $20 \mathrm{~h} 07 \mathrm{~min}$ & 650 & 380 & 7.02 & 0.54 \\
\hline & $20 \mathrm{~h} 15 \mathrm{~min}$ & 540 & 320 & 5.95 & 0.34 \\
\hline & $20 \mathrm{~h} 21 \mathrm{~min}$ & 720 & 420 & 6.00 & 0.24 \\
\hline & $08-30-2001$ & 1275 & 1055 & 6.32 & 0.32 \\
\hline
\end{tabular}

Samples for SEM-EDX examination were sprinkled onto $2 \mathrm{~cm}^{2}$ plates and carbon vaporized. Backscattered electron imaging (BEI) was used to locate the particles of interest. In that mode, brightness is related to the average atomic number of materials, and the mineral particles appear as bright spots within the organic matrix of sediment. The relative abundance of a given trace element carrier can then be assessed by conducting systematic microanalysis of bright spots. It should nevertheless be noted that this procedure largely overlooks mineral 
phases with low-atomic-number elements such as clays and carbonates. Statistics were conducted on about 100 trace element carriers identified per event. In order to increase the emission of backscattered electrons, the SEM microscope was generally operated with a beam current of $3 \mathrm{pA}$ and an accelerating voltage of $20 \mathrm{kV}$ (analysed microvolume of about $6 \mu \mathrm{m}^{3}$ ). However, to improve the quantification of low atomic number elements, EDX analysis was sometimes carried out at an accelerating voltage of $10 \mathrm{kV}$ (sampling volume of $3 \mu \mathrm{m}^{3}$ ).

\section{RESULTS AND DISCUSSION}

\section{Trace element speciation in sewage.}

Typical electron micrographs and corresponding EDX spectra of trace element carriers found in sewage are illustrated in figure 3. Particles of anthropic origin such as metallic alloys were easily recognized (fig. 3a-b). The ternary alloy of chemical composition (Fe $70 \pm 0.7 \%$, Ni $14.4 \pm 1.5 \%$, and Cr $15.5 \pm 1 \%$ ) identifies stainless steel which is used in a variety of outdoor and indoor materials such as kitchen ustensils or wall claddings (Kumar et al., 1994; Wallinder et al., 2002). The flake morphology of the particle in figure 3 a suggests removal under corrosive conditions (Wallinder et al., 2002). Particles containing Ni (61\%), Fe (18\%), and $\mathrm{Cr}(21 \%)$, associated with uses such as electrical resistances or thermocouple materials (Marucco, 1995), were also observed. Pb-Sn alloys (fig. 3b), generally used for soldering in zinc-works, pyrophyllite particles carrying $\mathrm{Zn}$ (2-3\%), probably originating from cosmetic products, provide other examples of heavy metal carriers directly related to human activity. Titanium oxides of various stoichiometry $\left(\mathrm{TiO}_{2}\right.$ rutile and anatase, $\mathrm{TiO}$, and $\left.\mathrm{Ti}_{2} \mathrm{O}_{3}\right)$ used as pigments, and zeolites present in washing powders, were also frequently found in sewage samples but always devoid of trace elements.

In contrast, mineral particles such as anapaite $\left(\mathrm{Ca}_{2-\mathrm{x}} \mathrm{Fe}_{\mathrm{x}}\right)\left(\mathrm{PO}_{4}\right)_{2}, 4 \mathrm{H}_{2} \mathrm{O}$, readily identified in TEM (fig. 3c), are likely formed within the sewer system. Indeed, this phosphate mineral is characteristic of slightly alkaline/reducing conditions, and is frequently detected in brackish and freshwater sediments (Stamatakis and Koukouzas, 2001). Anapaite particles were found to entrap zinc traces in their structure. Other phosphate species identified in sewage samples, include whitlokite $(\mathrm{Ca}, \mathrm{Mg})_{3}\left(\mathrm{PO}_{4}\right)_{2}$, and apatite $\left(\mathrm{Ca}_{5-\mathrm{x} / 2} \mathrm{Y}_{\mathrm{x} / 2}\right)\left(\mathrm{PO}_{4}\right)_{3-\mathrm{x}}\left(\mathrm{CO}_{3}\right)_{\mathrm{x}}$. Even though apatite has been reported to regulate heavy metal concentration in natural environments (Chen et al., 1997), neither phases carried trace elements. In addition, fluoride or chloride substitutions were never detected in the apatite structure. 

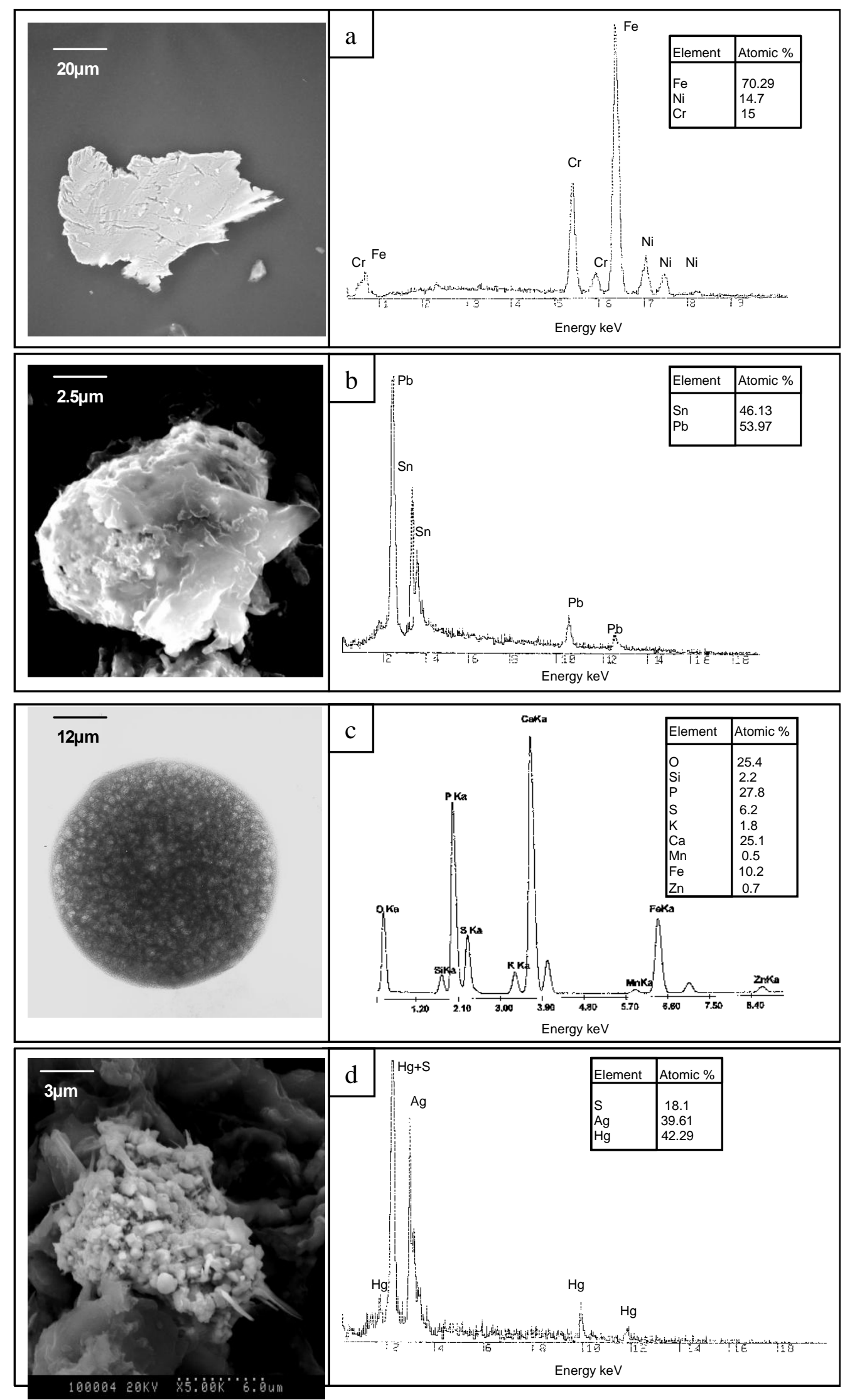

Figure 3. Electron micrographs and corresponding EDX spectra of typical particles in sewage. (a) BEI of stainless steel particle and (b) of Pb-Sn alloy. (c) TEM image of anapaite. (d) SEI of transformed amalgam particle. 
Sulfide particles found in sewage should also correspond to neoformed species. For instance, figure $3 \mathrm{~d}$ shows an electron micrograph of a binary sulfide of silver and mercury. The EDX spectrum reveals a non-stoichiometric relationship between $\mathrm{Ag}, \mathrm{Hg}$, and $\mathrm{S}$, characterized by a pronounced deficit in S. Some sulfur release under the electron beam may occur during analysis, and could account for such a deficit. However, the agglomerate aspect of the particle and the $\mathrm{Ag} / \mathrm{Hg}$ association are reminiscent of dental amagalm (Chern Lin et al., 2002; Acciari et al., 2001). As Ag and $\mathrm{Hg}$ are known to present a strong affinity for sulfur (Hesterberg et al., 2001), the observed particle could correspond to the transformation within the sewer of a piece of dental amalgam with fixation of reduced sulfur under anaerobic conditions. Another sulfide particle containing $\mathrm{Hg}, \mathrm{Ag}, \mathrm{Cu}$, and $\mathrm{Sn}$, could similarly be derived from the sulfurization of a dental amalgam. However, the most common metal sulfide minerals in sewage were monosulfides of $\mathrm{Fe}, \mathrm{Zn}$, and $\mathrm{Pb}$, with some binary sulfides of $\mathrm{Zn}-\mathrm{Fe}$ and $\mathrm{Cu}-\mathrm{Fe}$. In natural sediments, sulfide formation is usually associated with bacterial sulfate reduction, $\mathrm{H}_{2} \mathrm{~S}$ thus produced subsequently reacting with $\mathrm{Fe}^{2+}$ and trace metals (Morse et al., 1987; Herbert Jr. et al., 1998; Taillefert et al., 2000). As anoxic conditions are often encountered in stagnant portions of the sewer system (Hvitved-Jacobsen et al., 1995; Butler et al., 1995), precipitation of sulfide species can then be expected.

Iron oxides and oxihydroxide particles such as goethite, hematite, and maghemite, were frequently identified in dry weather. Although such minerals are generally considered as potential sinks for heavy metals (Bellanca et al., 1996; Fanfani et al., 1997), EDX spectra revealed that less than one third of iron oxides found in sewage were carriers of trace elements such as $\mathrm{Cr}, \mathrm{Cu}$, and $\mathrm{Zn}$.

\section{Trace element speciation in CSO (wet weather).}

Both sewage and surface runoff contribute to CSO. Runoff sources of trace elements include wet and dry atmospheric deposition, and specific release from urban surfaces such as highways (tires, automobile brakes), roofs and building siding, and from soil surfaces (garden, outcrops) (Mason et al., 1999; Davis et al., 2001). Resuspension of sewer sediment has also been demonstrated to represent a significant contaminant input (Gromaire et al., 1998; 2001). As shown in figures 4, 5, and 6, mineral particles from these various sources can be identified in CSO. 


\section{Contribution from urban surfaces}

Particles of barium sulfate, 10 to $20 \mu \mathrm{m}$ in size, were frequently observed in wet weather samples (fig. 4a). The electron diffraction pattern revealed crystallisation in an orthorhombic lattice, thus identifying barium sulfate particles as barite. Among the potential sources of barite in urban environment, automobile brake (inset of fig. 4a) and road paint are the most likely in wet weather. Barite particles would then originate from road runoff.

Micron size W-Cr-Co carbide granules (fig. 4b) are also probably flushed from the road surface. Indeed, these carbide particles are especially used as metal coating in vehicles to prevent wear and corrosion (Kusoffsky et al., 1997). The coating is applied to steel surface by air plasma spraying in presence of oxygen in order to promote the nucleation of oxycarbide (Murthy et al., 2001). This may explain the relatively high percentages of oxygen and $\mathrm{Fe}$ in the EDX spectrum.

Rare earth oxides such as the La-Ce particle shown in figure 4c, were exclusively found in CSO. These particles present excellent catalytic properties and they are generally used in association with cuprous oxide for gaz depollution in exhaust-pipes (Pestryakov and Davidov, 1996; Kili and Normand, 1999). Cuprite particles ( $\left.\mathrm{Cu}_{2} \mathrm{O}\right)$ were also evidenced in wet weather samples, and may be considered as a contribution from drained urban surfaces.

Franklinite ( $\left.\mathrm{Mn}_{1-\mathrm{X}} \mathrm{Zn}_{\mathrm{X}} \mathrm{Fe}_{2} \mathrm{O}_{4}\right)$ (fig. 4d), a face-centered cubic structure in which $\mathrm{Zn}$ is substituted for Mn, was identified in CSO by TEM-EDX. Although franklinite presents some applications as inductor in transformers and in loud-speakers (Guaita et al., 1999), this high temperature spinel is mainly known to be emitted during Zn-ore smelting operations and household waste incineration (Jdid et al., 2000); it is then likely to result from atmospheric deposition. 

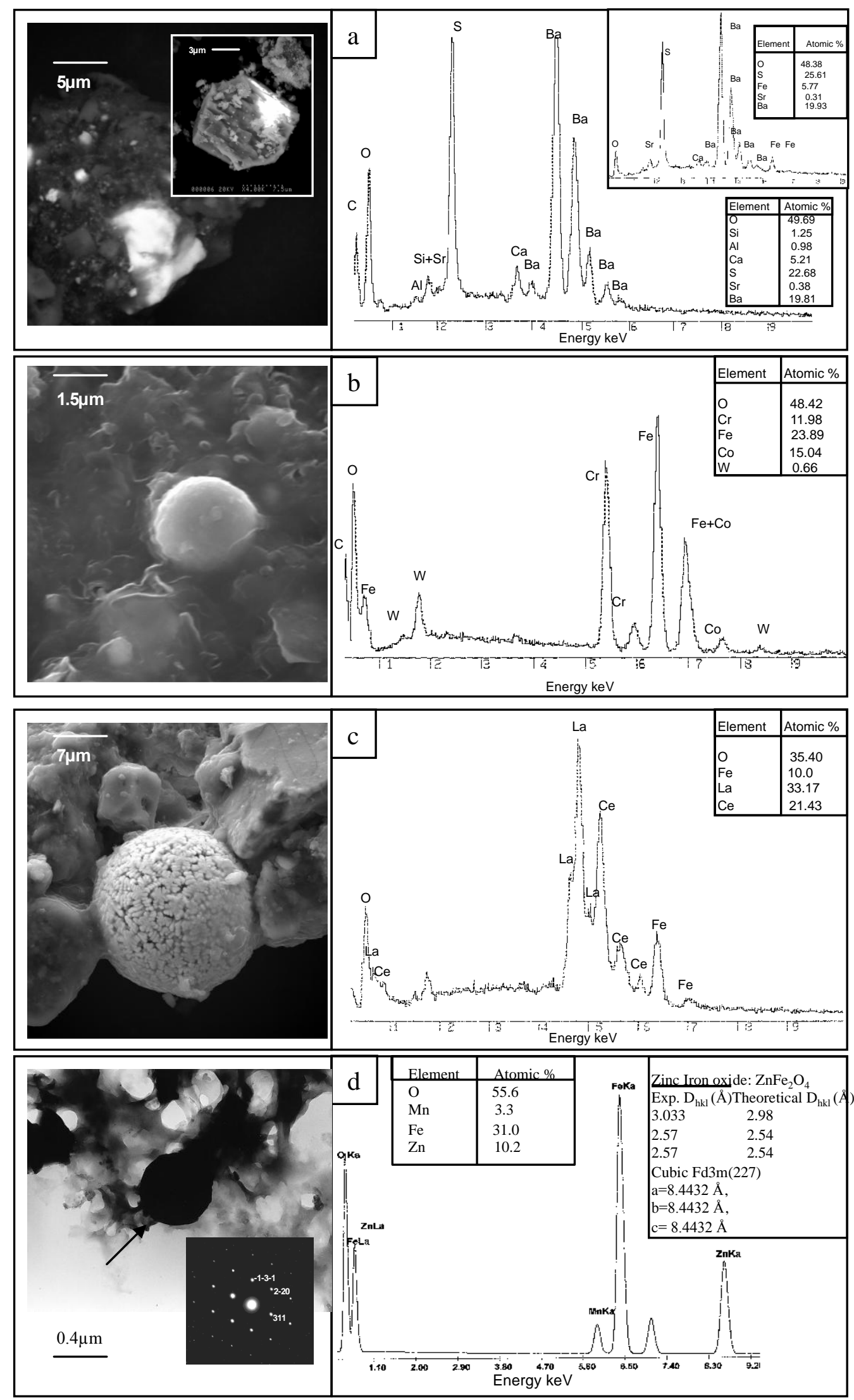

Figure 4. Electron micrographs and corresponding EDX spectra of typical urban surfaces particles. (a) BEI of barite in CSOs and barite of automobile brake (inset), (b) BEI of W-Cr- 
Co carbide. (c) SEI of rare earth oxide particle. (d) TEM image of franklinite particle and the corresponding diffraction pattern (inset).

\section{Contribution from sewer sediments}

CSO samples were found to be substantially enriched in sulfide particles. EDX analyses and microscopic observations revealed that the sulfide species occured in a wide range of composition and textural forms. Thus, iron sulfides were encountered both as framboid-like and well-crystallized particles (fig. 5a), with $\mathrm{Fe} / \mathrm{S}$ ratios close to 1:1, 1:2 and 3:4. Such iron-to-sulfur ratios identify mackinawite $(\mathrm{FeS})$, pyrite $\left(\mathrm{FeS}_{2}\right)$, and greigite (Fe3 $\left.\mathrm{S}_{4}\right)$, respectively. Coexistence of iron sulfides of variable composition has already been reported in freshwater canal sediments and anoxic marine sediments (e.g. Large et al., 2001; Cutter and Kluckholn, 1999; Schippers and Jorgensen, 2002). Mackinawite is a known precursor to pyrite formation (Herbert Jr et al., 1998; Lennie et al., 1997), whereas greigite has been shown to be easily formed by oxidation of mackinawite (Lennie et al., 1997), and is usually present in environments which show a seasonal oxic/anoxic cyclicity (Hilton, 1990).

Similarly, EDX microanalyses revealed that Zn-monosulfides occured as two main forms with $\mathrm{Zn} / \mathrm{S}$ elemental ratios of approximate $1: 1$ and 2:3. The 1:1 $\mathrm{ZnS}$ mineral phase corresponds to sphalerite which is commonly found in anaerobic sediments (Labrenz et al., 2000; O’Day et al., 2000; Large et al., 2001). On the other hand, the 2:3 stoichiometry has only been evidenced as nanoclusters that are intermediates in $\mathrm{ZnS}$ mineral formation (Luther III et al., 1999). Pb-monosulfide minerals were also found in CSO samples, but the overlap of $\mathrm{S} \mathrm{K} \alpha$ and $\mathrm{Pb} \mathrm{L} \alpha$ radiations make the EDX assessment of lead-to-sulfur ratios inaccurate.

Zinc, lead, and iron monosulfides represented respectively, 48.6\%, 22.4\%, and 9.3\% of all sulfide species observed in CSO samples. Other chalcophile elements occured as binary sulfides with stoichiometries close to that of chalcostibite $\left(\mathrm{CuSbS}_{2}\right)$ (fig. $\left.5 b\right)$ or chalcopyrite $\left(\mathrm{CuFeS}_{2}\right)$, and as traces associated with iron sulfide phases. All these sulfides certainly precipitate as a consequence of the reaction between dissolved heavy metals and reduced sulfur species derived from microbially-mediated sulfate reduction (Norsker et al., 1995). They accumulate in sewer sediments during dry weather and are resuspended in CSO during rain events. Such interpretation is consistent with Gromaire's observation that dissolved zinc, cadmium, copper, and lead concentrations are drastically reduced between the inlet and the outlet of the combined sewer (Gromaire et al., 2001). These authors attributed this decrease to a change in metal speciation within the sewer system. 

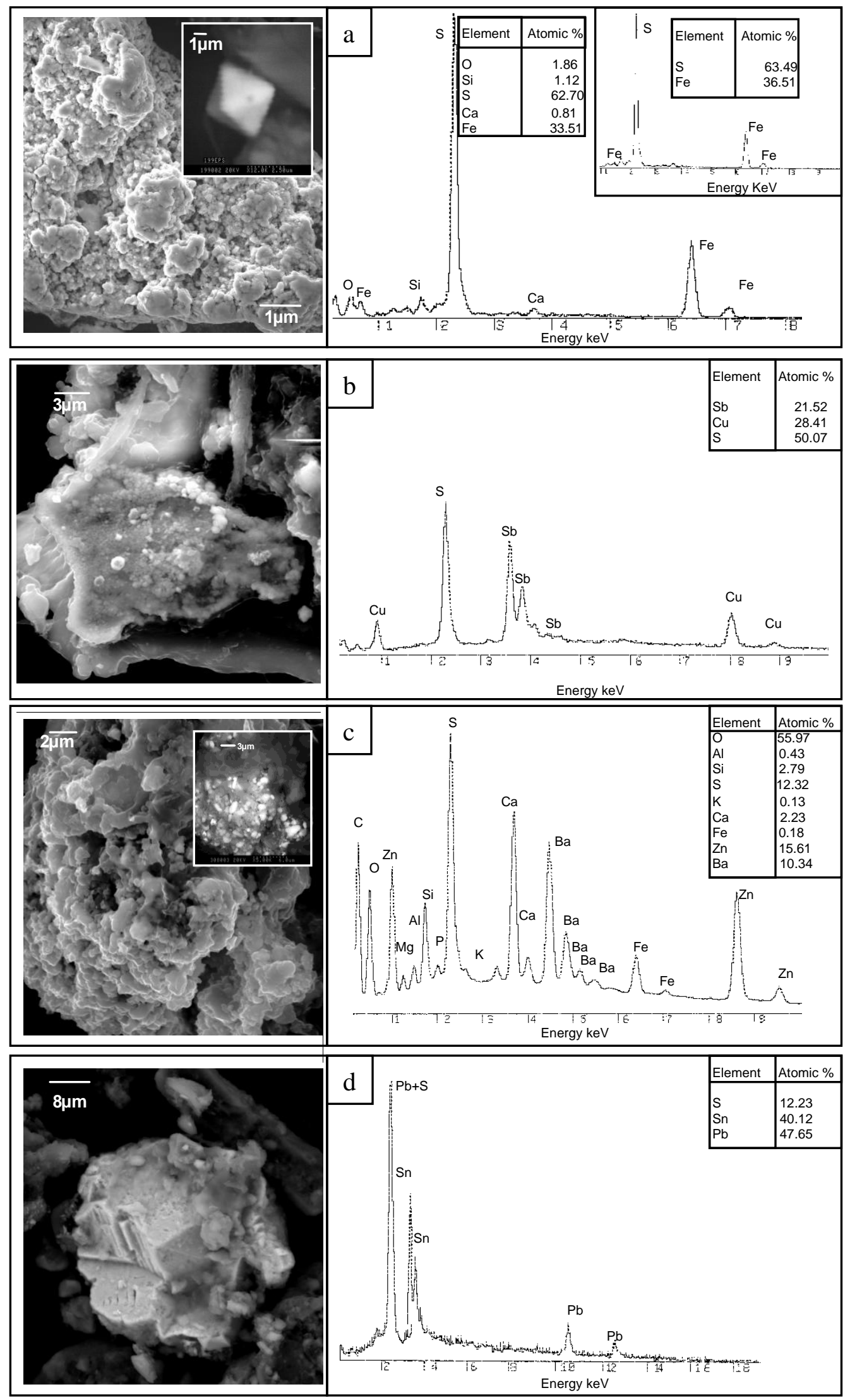

Figure 5. Electron micrographs and corresponding EDX spectra of typical particles from sewage sediments. (a) BEI of framboidal and well crystallized pyrite (inset). (b) SEI of 
Chalcostibite; (c) SEI and BEI (inset) of Zn-sulfide grains and barite. (d) SEI of transformed $\mathrm{Pb}$-Sn alloy. In situ formation of sulfides is also evidenced by the observation of sulfide coating on minerals allochtonous to the sewer. Thus, figure 5c shows SEI and BEI (inset) of $\mathrm{Zn}$-sulfide grains grown on a barite surface. Even though numerous sources of sulfur such as detergent surfactants or organic matter may be recognized in sewage (Matthijs et al., 1995; Hvitved-Jacobsen et al., 1995), the association barite-Zn sulfide suggests that $\mathrm{SO}_{4}$ from barite may be mobilized as sulfide by sulfate-reducing bacteria. The solid-phase transformation of some mineral particles in presence of $\mathrm{H}_{2} \mathrm{~S}$, already suggested by "dental amalgam-sulfides" found in dry weather samples, is further substantiated by the observation of particles such as the $\mathrm{Pb}-\mathrm{Sn}-\mathrm{S}$ phase presented in figure $5 \mathrm{~d}$. This particle displays obvious cleavage planes which were absent in the original alloy (fig. 3b), and EDX microanalysis revealed a small non-stoichiometric percentage of associated sulfur. This indicates that the $\mathrm{Pb}-\mathrm{Sn}$ alloy is instable in anoxic sewer sediments and evolves towards a sulfide phase.

\section{Contribution from soil surfaces}

Illite and kaolinite particles were frequently observed in wet weather samples by TEM-EDX (fig. 6a). The increased abundance of kaolinite was further confirmed by the presence of characteristic bands at 3698 and $3620 \mathrm{~cm}^{-1}$ (respectively, anti-symetric stretching of external and internal $\mathrm{OH}$ in kaolinite) in infrared spectra of freeze-dried CSO settleable fraction (El Samarani, 2003). Illite and kaolinite are known to be dominant minerals in terra fusca soils formed on the Bajocian calcareous parent rocks of the catchment area (Guillet et al., 1984). As a consequence, the presence of illite and kaolinite in wet weather samples indicates a contribution from soil surface runoff. Figure 5a shows an illite particle with a minor amount of $\mathrm{Zn}$. Clay minerals have been shown to be potential trace element carriers (Du et al., 1997). However, most clay particles identified in CSO samples were free of heavy metals. Phosphate phases found in dry weather samples such as anapaite or apatite, were not detected in CSO presumably because of sewage dilution by runoff. On the other hand, a variety of rare earth phosphate minerals such as La-Ce (monazite fig. 6b), La-Y, Eu-Th and La-Eu phosphates were identified in CSO. These phosphate minerals, originally formed in igneous rocks, are known to be stable phases in the sedimentation cycle (Cliff et al., 1991), and probably come from the sedimentary rocks of the catchment area. Also commonly observed in CSO samples are slightly rounded zircon particles (fig. 6c). Zircon, considered as the most resistant mineral to weathering and dissolution (Velbel, 1999), should also reflect outcrop erosion during rain events. 

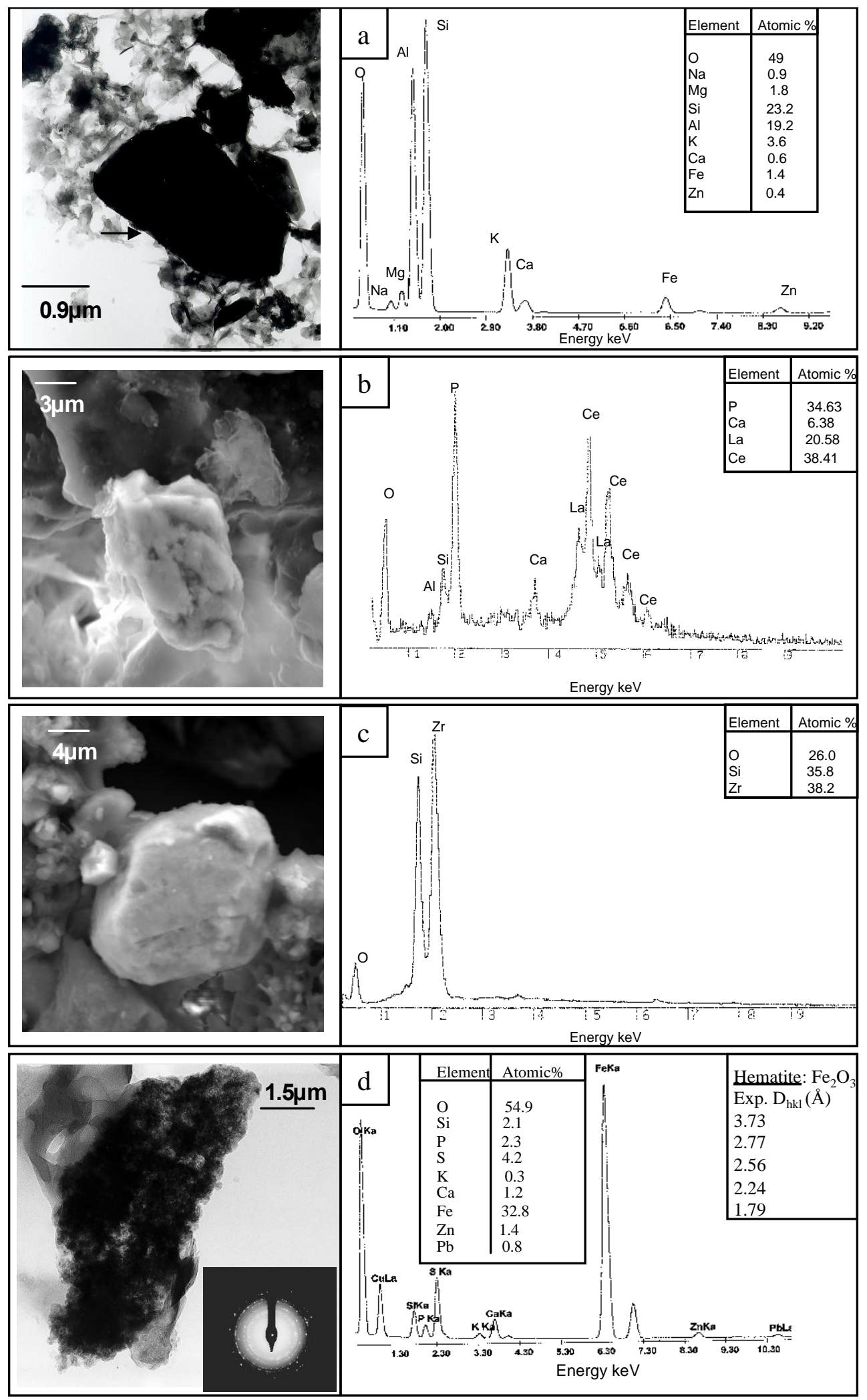

Figure 6. Electron micrographs and corresponding EDX spectra of particles found in CSO and likely originating from soil surfaces. (a) TEM image of kaolinite. (b) SEI of monazite. (c) SEI of zircon particles. (d) TEM image of hematite and corresponding electron diffraction pattern (inset). 
Iron oxihydroxide minerals such as ferrihydrite, goethite, and hematite (fig. 6d), were present in wet weather samples. However, in contrast with iron oxide phases observed in sewage, EDX microanalyses indicated that about half of iron particles in CSO entrapped heavy metal contaminants $(\mathrm{Zn}, \mathrm{Cu}, \mathrm{Cr}$ ), thus suggesting a different origin (table 2). The likely source of iron oxide particles during rain events is the terra fusca soil where goethite and hematite have been previously described (Guillet et al., 1984).

Table 2. Percentage of contaminated iron oxihydroxide species in settleable and suspended fractions of sewage and CSO of storms and weak rain events ( $\mathrm{n}=$ number of identified particles).

\begin{tabular}{|c|c|c|c|}
\hline \multirow{2}{*}{ Particle fraction } & \multicolumn{3}{|c|}{ Contaminated iron oxihydroxide species } \\
\cline { 2 - 4 } & Sewage (dry weather) & CSO (weak rain) & CSO (storm) \\
\hline Settleable & $29 \%(n=65)$ & $32 \%(\mathrm{n}=70)$ & $40 \%(\mathrm{n}=64)$ \\
\hline Suspended & $33 \%(\mathrm{n}=64)$ & $54 \%(\mathrm{n}=68)$ & $49 \%(\mathrm{n}=72)$ \\
\hline
\end{tabular}

Such contribution from soil runoff can be evidenced by plotting the relative abundance of particles identified by SEM-EDX as a function of time for a given storm event (6 july 2001). Indeed, figure 7a reveals that the highest proportion of iron oxihydroxides is shifted with regard to the peak of flow rate. This can be explained by the time needed to mobilize and transport particles from soil surfaces to the combined sewer. Such an interpretation is further supported by the fact that rare earth phosphates and most zircon particles observed in this storm event, were found in the three samples collected after $20 \mathrm{~h} 00$.

On the other hand, the evolution of sulfide abundance closely follows the flow rate dynamics (fig. 7b). This agrees with a pattern of sediment resuspension and redeposition as flow rate changes in the combined sewer during the rain event. In parallel of EDX microanalyses, a sequential extraction for heavy metals $(\mathrm{Zn}, \mathrm{Pb}, \mathrm{Cu}, \mathrm{Cd}, \mathrm{Cr}$ ) was conducted on CSO samples. It revealed that the oxidizable fraction represents the dominant contribution for $\mathrm{Zn} \mathrm{(30-46 \% ),} \mathrm{Cu}(31-55 \%)$, and $\mathrm{Cd}$ (35-56\%), while the exchangeable fraction was relatively insignificant for the same metals (El Samrani, 2003). As a consequence, the "first flush" effect, characterized by similar trends in flow rate and in heavy metal concentrations (Morrison et al., 1984), can be explained not only by urban surfaces runoff, but also by the mobilization of sulfide minerals formed in sewer sediments. In that case, the first flush would 
remain related to the length of the dry period preceding the rain (Sonzogni et al., 1980), as the stock in sulfide phases should principally increase during dry weather. Copper was also reported as mainly originating from the sewer sediment by Gromaire et al (2001).
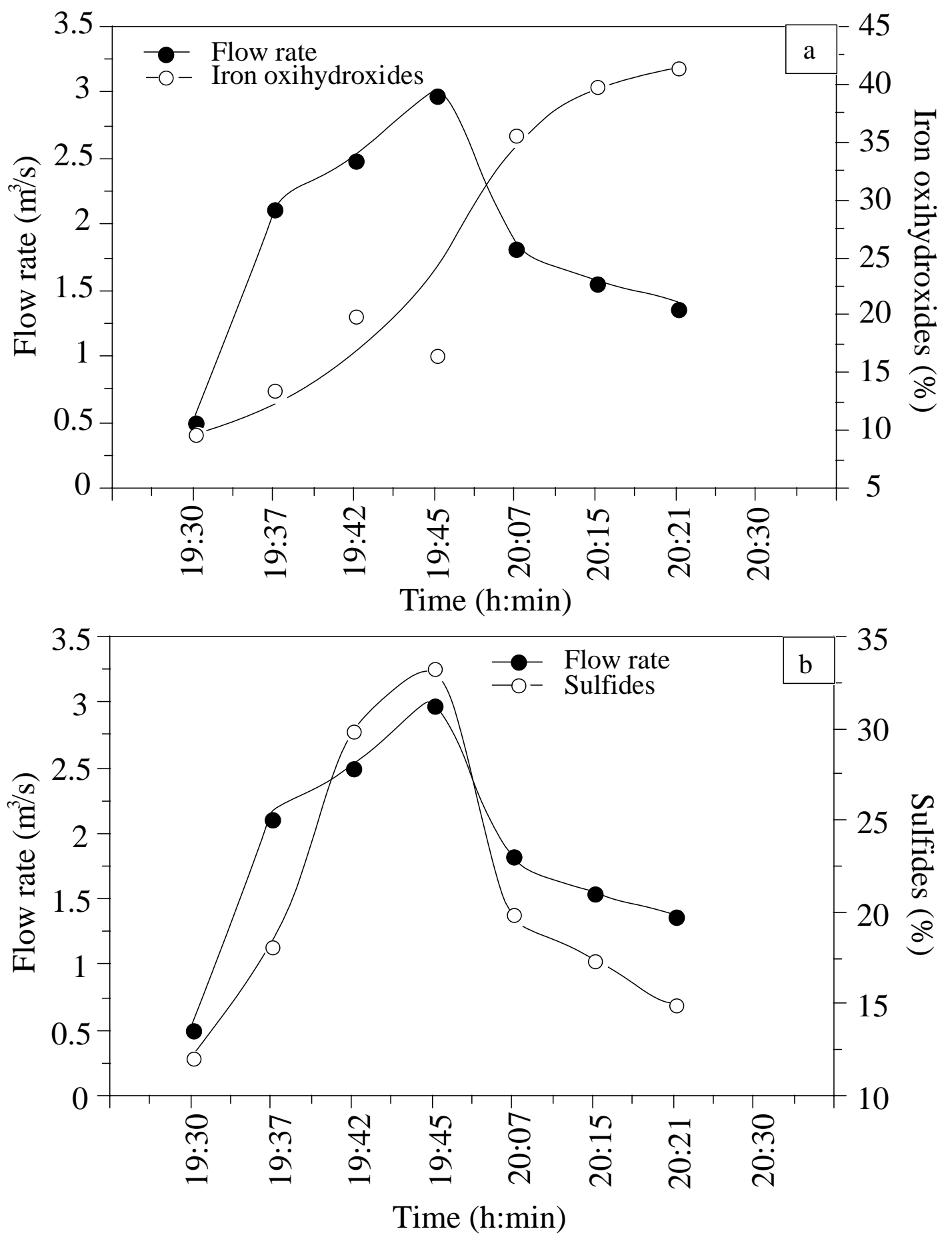

Figure 7. Flow rate and relative abundances of (a) iron oxyhydroxides and (b) heavy element sulfide particles during a storm event calculated with respect to the sum of the trace element carriers identified by SEM-EDX. 


\section{Abundance of heavy metal carriers}

The averaged distributions of trace element carrier abundances for sewage and CSO samples are illustrated in figure 8. Interestingly, sewage and CSO samples from storm events display similar patterns for settleable and suspended fractions, whereas the proportions of iron oxides and sulfide phases drastically differ in fractions of CSO samples generated by weak rain events. Many factors such as size distribution, grain shape, and density, influence the settling velocity of particles. It is then unlikely that, after 2 hours of settling, the relative abundances of various trace element carriers can be similar in settleable and suspended fractions. As the amount of volatile solids is particularly high in sewage and storm event samples (table 1), one possible explanation is that heavy metal carriers become enmeshed in organic matter during transport, and the deposition is then controlled by the hetero-aggregates thus formed.

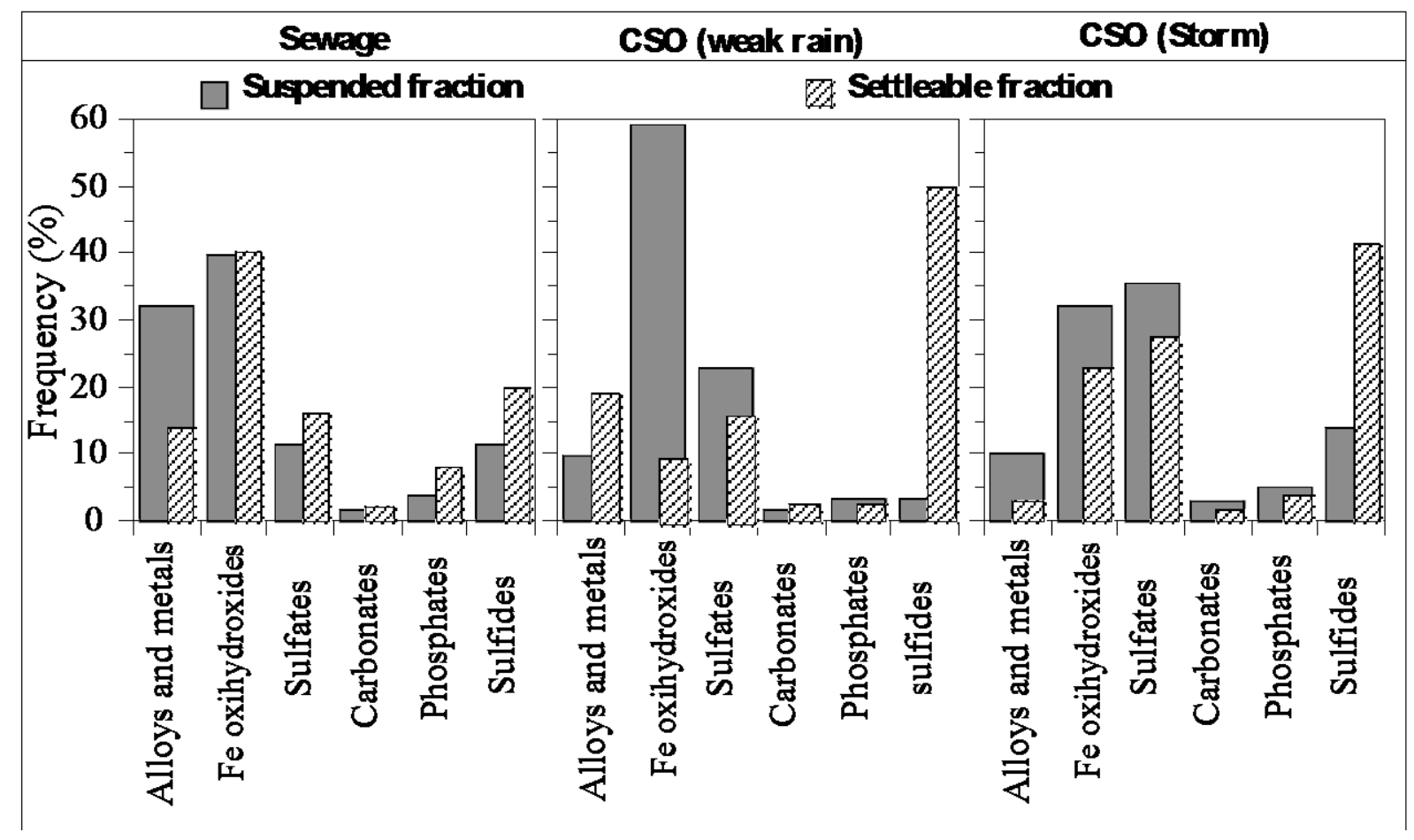

Figure 8. Distribution of trace element carriers relative abundances identified by SEM-EDX within suspended and settleable fractions of sewage and CSO during storms and weak rain events. 
It must be pointed out that the proportions of trace element carriers such as carbonates, clays, and organic matter, are largely underestimated by electron microscope examination if not completely overlooked. Thus, sequential extractions indicated that, in CSO samples, the dominant fraction of $\mathrm{Pb}$ was associated with carbonates and phosphates (36-51\%), while $\mathrm{Cr}$ showed a relatively high exchangeable fraction (9-16\%) (E1 Samrani, 2003). Particles of lead carbonates were detected by SEM-EDX in wet weather samples. Such lead carriers have been reported to be released from weathered paints (Barnes and Davis, 1996; Davis and Burns, 1999), although lead compounds such as cerusite are now forbidden in most paints.

Moreover, barite particles (96\% of sulfates) have been described in CSO as originating from paint and brake wear. However, their relatively high relative abundance $(16 \%)$ in sewage with respect to the other carriers suggests that another sources of barite such as medical application, may also contribute to their presence in sewage.

Finally, it was noticed that tunsgten carbide and $\mathrm{Pb}$-Sn alloys became much more frequent than stainless steel particles in wet weather samples. Such behavior is consistent with a re-suspension of high density alloys from sewer sediment during CSO events.

\section{Concluding remarks}

The main trace element carriers identified by TEM-EDX and SEM-EDX in sewage and combined sewer overflow, are summarized in table 3. Most metal contaminants are present under various mineral forms. Thus, in CSO samples, Zn was found associated with iron oxihydroxides, phosphates, clays, and occured predominantly as sulfide species. The chemical extraction also indicated that $\mathrm{Zn}$ was present to a lesser extent as exchangeable ions. Such a variety of physicochemical species implies that sludge retained in detention basins or generated by CSO treatment can only be disposed of in controlled landfills. In particular, such sludge can not be applied to land as heavy metals contained in sulfides will be released under oxidizing conditions. Electron microscope investigations always raise the problem of results representativity, especially on heterogeneous samples such as those studied here. Nevertheless, this approach appears rather fruitful to unravel geochemical cycling of heavy metals in urban environment. 
Table 3. Trace elements and corresponding carriers in sewage and CSO.

\begin{tabular}{|c|c|c|}
\hline \multirow{7}{*}{$\begin{array}{c}\text { Sewage } \\
\text { Dry weather }\end{array}$} & Alloys and metals & $(\mathrm{Pb})(\mathrm{Ag})(\mathrm{Fe}, \mathrm{Cr})(\mathrm{Fe}, \mathrm{Ni}, \mathrm{Cr})$ \\
\hline & Iron oxihydroxides & $(\mathrm{Pb}),(\mathrm{Cu}),(\mathrm{Cr}),(\mathrm{Mn}),(\mathrm{Cr}, \mathrm{Mn}),(\mathrm{Zn}, \mathrm{Cu})$ \\
\hline & Carbonates & $(\mathrm{Fe}, \mathrm{Pb})$ \\
\hline & Phosphates & $(\mathrm{Fe}),(\mathrm{Zn})$ \\
\hline & Sulfides & $\begin{array}{c}(\mathrm{Zn})(\mathrm{Pb})(\mathrm{Fe})(\mathrm{Ag})(\mathrm{Cu})(\mathrm{Cu}, \mathrm{Cr}, \mathrm{Fe}) \\
(\mathrm{Cu}, \mathrm{Sn}, \mathrm{Fe})(\mathrm{Cu}, \mathrm{Fe}, \mathrm{Sb}, \mathrm{Zn})(\mathrm{Ag}, \mathrm{Hg})\end{array}$ \\
\hline & Sulfates & $(\mathrm{Ba})(\mathrm{Ba}, \mathrm{Sr})$ \\
\hline & Clays & $(\mathrm{Zn})$ \\
\hline \multirow{7}{*}{$\begin{array}{c}\text { Combined } \\
\text { Sewer } \\
\text { Overflow }\end{array}$} & Alloys and metals & $\begin{array}{c}(\mathrm{Pb})(\mathrm{Ag})(\mathrm{W})(\mathrm{Ni}, \mathrm{Sn})(\mathrm{Fe}, \mathrm{Cu})(\mathrm{Fe}, \mathrm{Ni}, \mathrm{Cr}) \\
(\mathrm{Fe}, \mathrm{Ni}, \mathrm{Mn}, \mathrm{Cr})(\mathrm{W}, \mathrm{Fe}, \mathrm{Cr}, \mathrm{Co})\end{array}$ \\
\hline & Iron oxyhydroxides & $(\mathrm{Fe}, \mathrm{Zn})(\mathrm{Fe}, \mathrm{Zn}, \mathrm{Mn})(\mathrm{Fe}, \mathrm{Zn}, \mathrm{Cr})(\mathrm{Fe}, \mathrm{Pb}, \mathrm{Cu})$ \\
\hline & Carbonates & $(\mathrm{Pb})$ \\
\hline & Phosphates & $(\mathrm{La}, \mathrm{Ce})(\mathrm{Zn}, \mathrm{Fe})(\mathrm{Zn}, \mathrm{Pb})(\mathrm{Y}, \mathrm{Er}, \mathrm{Yb})$ \\
\hline & Sulfides & $\begin{array}{c}(\mathrm{Zn})(\mathrm{Pb})(\mathrm{Fe})(\mathrm{Ag})(\mathrm{Cu})(\mathrm{Zn}, \mathrm{Pb})(\mathrm{Zn}, \mathrm{Fe})(\mathrm{Fe}, \mathrm{Cu}) \\
(\mathrm{Fe}, \mathrm{Mn})(\mathrm{Cu}, \mathrm{Zn}, \mathrm{Fe})(\mathrm{Ag}, \mathrm{Hg}, \mathrm{Sn}, \mathrm{Cu})\end{array}$ \\
\hline & Sulfates & $(\mathrm{Ba})(\mathrm{Ba}, \mathrm{Sr})$ \\
\hline & Clays & $(\mathrm{Zn})$ \\
\hline
\end{tabular}

Acknowledgements. Financial support provided by Grand Nancy Urban Community is gratefully acknowledged. 


\section{REFERENCES}

Acciari H., Guastaldi A. and Brett C. (2001). Corrosion of dental amalgams: electrochemical study of Ag-Hg, Ag-Sn and Sn-Hg phases. Electrochem. Acta. 46, 3887-3893.

Barnes G. and Davis A. (1996). Dissolution of lead paint in aqueous solutions. J. Environ. Eng. July, 663-666.

Bedient P.B., Harned D.A., and Characklis W.G. (1978) Storm water analysis and prediction in Houston. J. Environ. Eng. Div. ASCE. 104, 1087-1100.

Bellanca A., Hauser S., Neri R. and Palumbo B. (1996). Mineralogy and geochemistry of Terra Rossa soils, western Sicily: insights into heavy metal fractionation and mobility. Sci. Tot. Environ. 193, 57-67.

Butler D., Xiao Y., Karunaratne S. and Thedchanamoorthy S. (1995). The gully pot as a physical, chemical and biological reactor. Wat. Sci. Tech. 31, 219-228.

Chebbo G., Mouchel J.M., Saget A. and Gousailles M. (1995). La pollution due aux rejets urbains par temps de pluie: flux, nature et impacts. TSM. 90, 796-806.

Chen X., Wright J., Conca J. and Peurrung L. (1997). Effects of pH on heavy metal sorption on mineral apatite. Environ. Sci. Technol. 31, 624-631.

Chern Lin J., Chen K. and Ju C. (2002). Transmission electron microscopic study of early stage $\gamma 1(\mathrm{Ag} 2 \mathrm{Hg} 3)$ and $\beta 1(\mathrm{Ag}-\mathrm{Hg})$ phases, Technical note. Dental Mat. 18, 422-424.

Cliff R.A., Drewery S.A., Leeder M.R., 1991, Sourcelands for the carboniferous Pennine river system: constraints from sedimentary evidence and $\mathrm{U}-\mathrm{Pb}$ geochronology using zircon and monazite. In: Morton, A.C., Todd, S.P., Haughton P.D.W. (Eds.), Developments in Sedimentary Provenance Studies. Geol. Soc. London, Spec. Publ. 57, 137-159. 
Cutter G. and Kluckholn R. (1999). The cycling of particulate carbon, nitrogen, sulfur, and sulfur species (iron monosulfides, greigite, pyrite, and organic sulfur) in the water columns of Framvaren Fjord and the Black Sea. Mar. Chem. 67, 149-160.

Davis A. and Burns M. (1999). Evaluation of lead concentration in runoff from painted structures. Wat. Res. 33, 2949-2958.

Davis A., Shokouhian M. and Ni S. (2001). Loading estimates of lead, copper, cadmium, and zinc in urban runoff from specific sources. Chemosphere. 44, 997-1009.

De Boer D. and Crosby G. (1995). Evaluating the potential of SEM/EDS analysis for fingerprinting suspended sediment derived from two contrasting topsoils. Catena. 24, 243258.

Du Q., Sun Z., Forsling W. and Tang H. (1997). Adsorption of copper at aqueous illite surfaces. J. Colloid Interface Sci. 187, 232-242.

Ellis, J.B. and Hvitved-Jacobsen T. (1996) Urban drainage impacts on receiving waters. $J$. Hydraulic Res. 34 (6), 771-783.

El Samrani A. G. (2003). Dépollution des eaux pluviales: Spéciation des éléments traces et optimisation du traitement de coagulation-floculation. Thèse, INPL-Nancy-FRANCE

Fanfani L., Zuddas P. and Chessa A. (1997). Heavy metals speciation analysis as a tool for studying mine tailings weathering. J. Geochem. Explor. 58, 241-248.

Florence TM. Morrison G.M. and Stauber J.L. (1992). Determination of trace element speciation and the role of speciation in aquatic toxicity. Sci. Tot. Environ. 125, 1-13.

Förster J. (1996). Patterns of roof runoff contamination and their potential implications on practice and regulation of treatment and local infiltration. Wat. Sci. Technol. 33 (6), 39-48.

Gromaire M.C., Chebbo G. and Saad M. (1998). Origins and characteristics of urban wet weather pollution in combined sewer systems: the experimental urban catchment "le Marais " in Paris. Wat. Sci. Technol. 37, 35-43. 
Gromaire M.C., Garnaud S., Saad M. and Chebbo G. (2001). Contribution of different sources to the pollution of wet weather flows in combined sewers. Wat. Res. 35 (2), 521-533.

Guaita F., Beltran H., Cordoncillo E., Carda J. and Escribano P. (1999). Influence of the precursors on the formation and the properties of $\mathrm{ZnFe}_{2} \mathrm{O}_{4}$. J. Eur Soc. 19, 363-372.

Guillet B., Burtin G., Delcroix P. and Gury M. (1984). Le fer des calcaires et des terra fusca des plateaux lorrains (France). Pedologie. XXXIV 3, 301-318.

Herbert Jr. R., Benner S., Pratt A. and Blowes D. (1998). Surface chemistry and morphology of poorly crystalline iron sulfides precipitated in media containing sulfate-reducing bacteria. Chem. Geol. 144, 87-97.

Hesterberg D., Chou J., Hutchison K., and Sayers D. (2001). Bonding of Hg(II) to reduced organic sulfur in humic acid as affected by $\mathrm{S} / \mathrm{Hg}$ ratio. Environ. Sci. Technol. 35, 2741-2745.

Hilton J. (1990) Greigite and the magnetic properties of sediments. Limnol. Oceanogr. 35, 509-520.

Hvitved-Jacobsen T., Raunkjaer K. and Nielsen P. (1995). Volatile fatty acids and sulfide in pressure mains. Wat. Sci. Technol. 31, 169-179.

Jdid E., Yvon J., Barrès O. and Lhote F. (2000). Evaluation du comportement à long terme des résidus fins d'incinération des ordures ménagères (REFIOM) stabilisés aux liants hydrauliques. Laboratoire Environnement et Minéralurgie. Rapport de la convention LIFE 99. Env/B-000638- 45p

Kili K. and Normand F. (1999). Modification of the catalytic properties of palladium by rare earth (La, Ce) addition, Catalytic activity and selectivity in hydrocarbon conversion. J. Molec. Catal. A: Chem. 140, 267-285.

Kumar R., Srivastava K. and Srivastava P. (1994). Leaching of heavy metals (Cr, Fe, and Ni) from stainless steel utensils in food simulants and food materials. Bull. Environ. Contam. Toxicol. 53, 259-266. 
Kusoffsky A. and Jansson B. (1997). A thermodynamic evaluation of the Co-Cr and the CCo-Cr systems. Calphad. 21, 321-333.

Labrenz M., Druschel G., Thomsen-Ebert T., Gilbert B., Welch S., Kemmer K., Logan G., Summons R., De Stasio G., Bond P., Lai B., Kelly S. and Banfield J. (2000). Formation of sphalerite $(\mathrm{ZnS})$ deposits in natural biofilms of sulfate-reducing bacteria. Science. 290, 17441747.

La Force M.J. and Fendorf S. (2000) Solid-Phase iron characterization during common selective sequential extractions. Soil Sci. Soc. Am. J. 64, 1608-1615.

Lake D.L., Kirk P.W.W. and Lester J.N. (1984). Fractionation, characterization, and speciation of heavy metals in sewage sludge and sludge -amended soils: A review. $J$. Environ. Qual. 13 (2), 175-183.

Large D., Fortey N., Milodowski A., Christy A. and Jodd J. (2001). Petrographic observation of iron, copper, and Zinc sulfides in freshwater canal sediment. J. Sedim. Res. 71, 61-69.

Laurensot F. (1998). Caractérisation de la charges métallique des eaux de temps de pluie, Contribution des différents réservoirs à la pollution des eaux de temps de pluie. Rapport final, LHRSP, Nancy-France. $45 \mathrm{p}$.

Lee J. and Bang W. (2000). Characterization of urban stormwater runoff. Wat. Res. 34 (6), 1773-1780.

Lennie A., Redfern S., Champness P., Stoddart C., Schofield P. and Vaughan D. (1997). Transformation of mackinawite to greigite: An in situ X-ray powder diffraction and transmission electron microscopy study. Amer. Miner. 82, 302-309.

Luther III. G., Theberge S. and Rickard. (1999). Evidence for aqueous clusters as intermediates during Zinc sulfide formation. Geochim. Cosmochim. Acta. 63, 3159-3169.

Marchand A., Badot R., De Belly B. and Romain M. (1993). Les bassins de retention des eaux pluviales-Mode d'emploi. NANCIE, 222p. 
Marucco A. (1995). Phase transformations during long term ageing of Ni-Fe-Cr alloys in the temperature range $450-600^{\circ}$ C. Mat. Sci. Eng. A. 194, 225-233.

Mason Y., Ammann A., Ulrich A. and Sigg L. (1999). Behavior of heavy metals, nutrients, and major components during roof runoff infiltration. Environ. Sci. Technol. 33, 1588-1597.

Matthijs E., Debaere G., Itrich N., Masscheleyn P., Rottiers A., Stalmans M. and Federle T. (1995). The fate of detergent surfactants in sewer systems. Wat. Sci. Tech. 31, 321-328.

Michelbach S and Weib G. (1996). Settleable sewer solids at stormwater tanks with clarifier for combined sewage. Wat. Sci. Tech. 33, 261-267.

Morse J., Millero J., Cornwell J., and Rickard D. (1987). The chemistry of the hydrogen sulfide and iron sulfide systems in natural waters. Earth-Sci. Rev. 24, 1-42.

Morrison G.M., Revitt D.M., Ellis J.B., Svensson G., Balmer P. (1984). Variations of dissolved and suspended solid heavy metals through an urban hydrograph. Environ. Technol. Lett. 7, 313-318.

Morrison G.M.P and Revitt D.M. (1987). Assessement of metal species bioavailability and geochemical mobility in polluted waters. Environ. Technol. Lett. 8, 361-372.

Morrison G.M., Revitt D.M. and Ellis J.B. (1989). Sources of storm loading variations of metal species in a gollypot catchment. Sci. Tot. Environ. 80, 267-278.

Murthy J., Rao D. and Venkataraman B. (2001). Effect of grinding on the erosion behaviour of a WC-Co-Cr coating deposited by HVOF and detonation gun spray processes. Wear. 249, 592-600.

Norsker N., Nielsen P. and Hvitved-Jacobsen T. (1995). Influence of oxygen on biofilm growth and potential sulfate reduction in gravity sewer biofilm. Wat. Sci. Technol. 31, 159167.

O’Day P., Carrol S., Randall S., Martinelli R., Anderson S., Jelinski J. and Knezovich J. (2000). Metal speciation and bioavailability in contaminated estuary sediments, Almenda Naval air station, California. Environ. Sci. Technol. 34, 3665-3673. 
Ostergren J.D., Brown G.E. Jr., Parks G.A., Tingle T.N. (1999) Quantitative speciation of lead in selected mine tailings from Leadville, Co. Environ. Sci. Technol. 33. 1627-1636.

Perin G., Fabris R., Manente S., Rebello Wagener A., Hamacher C. and Scotto S. (1997). A five-year study on the heavy metal pollution of Guanabara Bay sediments (Rio De Janeiro, Brazil) and evaluation of the metal bioavailability by means of geochemical speciation. Wat. Res. 31 (12), 3017-3028.

Pestryakov A. and Davydov A. (1996). The infuence of modifying additions of La and Ce oxides on electronic state of surface atoms and ions of supported copper. Appli. Surf. Sci. 103, 479-483.

Serne R.J. (1975). Geochemical distribution of selected trace metals in San Fransisco bay sediments. Water and Waste Management Section, Batelle, Pacific NorthWest Laboratories, Richland Washington.

Schippers A. and Jorgensen B. (2002). Biogeochemistry of pyrite and iron sulfide oxidation in marine sediments. Geochim. Cosmochim. Acta. 66, 85-92.

Sonzogni W.C., Chesters G., Coote D.R., Jeffs D.N. (1980). Pollution from land Runoff. Environ. Sci. Technol. 14, 148-153.

Stamatakis M.G. and N.K. Koukouzas (2001) The occurence of phosphate minerals in lacustrine clayed diatomite deposits, Thessaly, Central Greece. Sedim. Geol., 139, 33-47.

Taillefert M., Lienemann C-P., Gaillard J-F. and Perret D. (2000). Speciation, reactivity, and cycling of $\mathrm{Fe}$ and $\mathrm{Pb}$ in a meromictic lake. Geochim. Comochim. Acta. 64, 169-183.

Tessier A., Campbel P.G.C. and Bisson M. (1979). Sequential extraction procedure for the speciation of particulate trace metals. Anal. Chem. 51 (7), 844-851.

Velbel, M.A. (1999). Bond strength and the relative weathering rates of simple orthosilicates. Am. J. Sci. 299, 679-696. 
Wallinder I., Lu J., Bertling S. and Leygraf C. (2002). Release rates of chromium and nickel from 304 and 316 stainless steel exposure -a combined field and laboratory study. Corrosion Sci. 44, 2303-2319.

Zaggia L. and Zonta R. (1997). Metal-Sulphide formation in the contaminated anoxic sludge of the Venice canals. Appl. Geochim. 12, 527-536. 